\title{
Sykepleiere bør læere å utnytte placeboeffekten
}

Den terapeutiske styrken i placeboeffekten kan være like virksom som medisin. Placebo kan også forsterke effekten av medisinsk behandling og redusere bivirkninger av virksomme medisiner.

\section{Oddveig Birkeflet}

Sykepleier og akupunktør

Portalen helse

Placebo

Alternativ behandling

Sykepleien 2021109 (85745) (e-85745)

DOI: 10.4220/Sykepleiens.2021.85745

\section{Hovedbudskap}

Sykepleiere kan bidra til at medisinsk behandling får bedre effekt ved å utnytte ny kunnskap om placebofenomener. Da må det utarbeides kunnskapsbaserte metoder og etiske retningslinjer for bruk av placebo. Skjult bruk av placebo bør forbys, og sykepleierstudenter bør undervises om placebomekanismer og hvordan disse kan utnyttes terapeutisk og på en etisk forsvarlig måte.

Placebo er en uvirksom behandling uten spesifikke terapeutiske egenskaper. Det skilles mellom placeborespons og placeboeffekt. En placeborespons er individets endringer i helsetilstand etter en inaktiv behandling. 
Slike responser ser vi gjerne i kontroll- eller placebogruppen i et klinisk fors $\varnothing \mathrm{k}$. Hvis kontrollgruppen behandles med sukkerpiller, kan endringer $\mathrm{i}$ helsetilstanden skyldes naturlig sykdomsforløp eller regresjon mot gjennomsnittet. Differansen mellom endringer i helsetilstanden til deltakerne i placebogruppen og endringer i en gruppe som ikke får noen behandling, er placeboeffekten (1).

Placeboeffekten er dermed den forbedrede helsetilstanden over tid, på gruppenivå. Effekten forklares gjennom placebomekanismer (1), som jeg vil komme nærmere inn på straks.

Motstykket til placebo er nocebo. En noceborespons er når negative forventninger kan lede til en klinisk forverring (2).

\section{Forventninger endrer hjernen}

Placeboforskningen har kartlagt nevrobiologiske og psykologiske placebomekanismer som viser at hjernen kan påvirke den fysiske helsen. Placeboeffekten kan fremkalles av psykobiologiske faktorer.

Psykologiske faktorer i behandlingen er blant annet ord, verbal eller nonverbal kommunikasjon. Det er situasjonsavhengige stikkord, symboler, meninger og hele ritualet rundt den terapeutiske handlingen. Disse faktorene bidrar til å skape en forventning om en terapeutisk effekt av behandlingen. Forventninger kan skape endringer i hjernen, som igjen kan forbedre pasientens prognose $(1,2)$.

\section{«Håp og forventninger må være realistiske og skapes uten å lyve.»}

Placeboeffekten kan utnyttes i pasientomsorgen til å oppnå symptomatisk lindring ved mange medisinske tilstander. Motsatt kan negative verbale antydninger skape negative forventninger og kan medføre klinisk forverring, en noceboreaksjon. Forventninger om ubehag kan føre til økt smerteopplevelse (2). 
Helsepersonell bør unngå å skape noceboreaksjoner, og b $\varnothing \mathrm{r}$ kunne mestre verktøyene for å utnytte de helsefremmende fordelene av placeboeffekten. Institusjoner som utdanner helsepersonell, bør inkludere kunnskap om placebomekanismer i sine læreplaner. Sykepleiere og leger bør skoleres i hvordan mekanismene påvirker pasientenes helse, og hvordan de kan utnyttes terapeutisk på en etisk forsvarlig måte. Håp og forventninger må være realistiske og skapes uten å lyve.

\section{Er placebo bedrag eller behandling?}

Placebo blir ofte omtalt som narremedisin, for eksempel når inaktiv medisin gis til kontrollgrupper, eller når vitaminer, antibiotika eller smertestillende eller beroligende medisiner forskrives for tilstander de ikke er indikert for.

I noen tilfeller blir pasienten ikke informert om at medisinen er uvirksom mot tilstanden, eller at den har potensielle bivirkninger. Slik skjult bruk av placebo reiser etiske spørsmål om bedrag, og bør forbys.

Det er ikke nødvendig å bedra pasienten for å oppnå placeboeffekt. Effekten kan oppnås ved å forklare at bedring kan bero på andre faktorer enn selve behandlingen, slik som forventninger til prognosen (1). Sykepleiere kan aktivere placebomekanismene som en del av ekte terapi ved å fremheve gode forventninger til behandlingen (2). Optimal bruk av placeboeffekt kan bidra til bedre terapeutisk effekt og bør utnyttes som en del av vanlig behandling (3).

\section{Tillit til behandlingen er avgjørende}

Deltakere i kliniske studier, blant annet i studier av kirurgiske behandlingsformer, har blitt spurt om hvilken gruppe de tror de har blitt randomisert til. De som trodde de kom i behandlingsgruppen, fikk større klinisk forbedring enn de som trodde de havnet i placebogruppen. Reell gruppetildeling spilte ingen rolle for behandlingseffekten. Det som var avgjørende, var hvorvidt deltakerne trodde på behandlingen og forventet at den skulle hjelpe dem (2). 


\section{«Placeboet alene vil kunne indusere en betinget respons med like god smertestillende effekt.»}

Dersom pasienten får tillit til, og tror, at den behandlingen han eller hun får, er virkningsfull, vil det ha en gunstig effekt for resultatet. Sykepleiere kan forsterke effekten av en klinisk intervensjon. Gjennom omsorg, gjensidig respekt og et engasjert forhold til pasienten kan placebomedierte fordeler oppnås $(1,3)$. I tillegg til å tilrettelegge for gode pasientinteraksjoner kan sykepleiere verbalt skape forventninger om gode utfall av behandlingen, og de kan benytte læringsmekanismer for placebo.

Et eksempel på aktivering av en læringsmekanisme er å gi smertestillende tabletter sammen med et placebo, gjentatte ganger. Etter hvert vil placeboet alene kunne indusere en betinget respons med like god smertestillende effekt som den aktive medisinen (3). Denne mekanismen kan bidra til å hjelpe pasienter med å redusere dosen av smertestillende medisiner og unngå bivirkninger.

\section{Medisin bør administreres åpent}

Et godt pasient-sykepleier-forhold skaper tillit. Varme og empati er viktige egenskaper hos en sykepleier, og kan bidra til at også den medisinske kommunikasjonen kan ha placeboeffekter. Pasienter som blir behandlet under et støttende pasient-terapeut-forhold, får bedre lindring for sine plager enn pasienter som får minimal omsorg $(1,3)$.

Studier har sammenliknet skjult og åpen administrering av smertestillende medisiner. Et eksempel på skjult administrering er at perifert venekateter koples til en medisinpumpe eller en forlengelsesslange som kan føres bak en vegg. Medisineringen skjules dermed for pasienten.

\section{«Medisin har bedre effekt og krever mindre dosering når den administreres åpent.»}


Ved åpen administrering får pasienten vite når og hva han eller hun får av medisin, og kan kommunisere med sykepleieren. Medisin har bedre effekt og krever mindre dosering når den administreres åpent, i gode omgivelser og på en omsorgsfull måte (4).

Det samme er påvist ved bruk av akupunktur som smertelindring. To grupper som fikk henholdsvis ekte og falsk akupunktur, ble unders $\varnothing$ kt med MR. Det ble ikke funnet forskjell i smertelindring mellom gruppene. Derimot var smertelindringen signifikant blant dem som evaluerte terapeutforholdet til å være av god kvalitet.

Studien fant at smertelindringen ble formidlet gjennom pasient-terapeut-forholdet, nonverbal atferd og sosial speiling, som handler om å gi pasienten full oppmerksomhet gjennom for eksempel øyekontakt, stemmebruk og kroppsspråk (5). Funnene underbygger at sykepleiere kan fremme effekten av medisinsk behandling gjennom et godt pasientforhold.

\section{God kommunikasjon kan forebygge nocebo}

Informasjon skal være saklig. Likevel kan sykepleiere velge betryggende ord som fremhever den terapeutiske nytten, fremfor å fokusere på smerten pasienten kan oppleve under prosedyren. Prosedyreinformasjon som også inneholder fordeler med behandlingen, gir mindre behov for medisinering hos postoperative pasienter med smerte og angst $(1,3)$.

Gode strategier for optimal verbal og nonverbal kommunikasjon kan forebygge at det danner seg negative forventninger når pasienten blir informert om risiko og bivirkninger. Det kan forebygge noceboeffekter som kan forverre det terapeutiske utfallet $(1,3)$. 


\section{Negativ kommunikasjon kan spre sykdom}

Negativ informasjon og kommunikasjon deles raskt og kan forplante seg videre til mange mennesker. Slik kan kommunikasjon bidra til at symptomer sprer seg i befolkningen.

Høydesykeforskningen har vist hvordan det sosiale miljøet kan bidra til å spre sykdom blant folk. Negativ informasjon om risikoen for å utvikle hodepine ved store høyder ble gitt til en person, en utløser.

Utløseren spredde informasjonen videre via andre personer (nocebogruppen).

\section{«Helsepersonell som uttaler seg til mediene, bør tenke over noceboeffektene.»}

På en uke nådde informasjonen 36 individer.

Nocebogruppen fikk signifikant økning på markører

for høydesyke og hodepine sammenliknet med en kontrollgruppe under samme høydeforhold (2).

Over en lengre periode kan hundrevis av individer bli «sosialt infisert». Dette viser betydningen av negativ sosial kommunikasjon i å spre symptomer og sykdom gjennom populasjonen (2).

Helsepersonell som uttaler seg til mediene, bør tenke over disse noceboeffektene. Tekster bør kvalitetssikres, som denne aktuelle overskriften i Nettavisen: «Leger mener folk må advares om bivirkningene av koronavaksinen: - Dette blir ingen dans på roser» (6).

Overskriften inneholder både nocebotriggere og en forventning om bivirkninger. Det gjør det vanskelig å få skeptikere til å vaksinere seg, og å avgjøre om eventuelle bivirkninger er faktiske eller skyldes nocebo. 


\section{Sykepleiere bør kurses i placebobruk}

Den terapeutiske styrken i placebo kan være like virksom som medisin. Placebo kan forsterke effekten av medisinsk behandling, og bivirkninger av virksomme medisiner kan reduseres (7). Placebo kan utnyttes for å fremme pasientens helse i alle deler av sykepleien hvor sykepleiere er i kontakt med pasienten.

Anvendelse av placebo som medisin er relativt nytt.

Derfor er det nødvendig at sykepleiere setter seg inn $\mathrm{i}$ emnet, og at det utarbeides et «placebokurs» som inngår i sykepleierutdanningen. Kurset kan bevisstgjøre sykepleiere på hvordan verbal og nonverbal kommunikasjon påvirker pasientens helse. Det kan undervises om placebomekanismer og om hvordan disse kan utnyttes terapeutisk, på en etisk forsvarlig måte.

I samarbeid med leger kan placebo brukes til å redusere medisindosering. Slik bruk kan være aktuelt blant annet ved plagsomme bivirkninger, ved avvenning, ved immunterapi og $\mathrm{i}$ behandlingen av Parkinsons sykdom.

\section{Referanser}

1. Evers AWM, Colloca L, Blease C, Annoni M, Atlas LY, Benedetti F, et al. Implications of placebo and nocebo effects for clinical practice: expert consensus. Psychotherapy and Psychosomatics. 2018;87(4):204-10.

2. Colloca L, Jonas WB, Killen J, Miller FG, Shurtleff D. Reevaluating the placebo effect in medical practice. Z Psychol. 2014;222(3):124-7.

3. Benedetti F. Placebo effects: from the neurobiological paradigm to translational implications. Neuron. 2014;84(3):623-37. 
4. Annoni M. Exceptional lies: the ethics of

deceptive placebos in clinical settings. Centro Einaudi. 2015;50(213). Tilgjengelig fra:

https://www.centroeinaudi.it/biblioteca-dellaliberta/edizione-online/189-anno-xlix,-n-213,-maggioagosto-2015/9084-exceptional-lies-the-ethics-ofdeceptive-placebos-in-clinical-settings.html (nedlastet 14.04.2021).

5. $\quad$ Ellingsen DM, Isenburg K, Jung C, Lee J, Gerber J, Mawla I, et al. Dynamic brain-to-brain concordance and behavioral mirroring as a mechanism of the patient-clinician interaction. Science Advances. 2020;6(43).

6. Karlsen MØ. Leger mener folk må advares om bivirkningene av koronavaksinen: - Dette blir ingen dans på roser. Nettavisen. 25. november 2020. Tilgjengelig fra:

https://www.nettavisen.no/nyheter/leger-mener-folkma-advares-om-bivirkningene-av-koronavaksinendette-blir-ingen-dans-pa-roser/s/12-95-3424052545 (nedlastet 14.04.2021).

7. Walach H. Reconstructing the meaning effect the capacity to self-heal emerges from the placebo concept. Tidsskrift for Forskning i Sygdom og Samfund. 2015;12(23):28. 